\title{
Effects of Fuel Reduction Treatments on Incidence of Phytophthora Species in Soil of a Southern Appalachian Mountain Forest
}

I. M. Meadows, D. C. Zwart, and S. N. Jeffers, Department of Entomology, Soils, and Plant Sciences; T. A. Waldrop, USDA Forest Service, Southern Research Station; and W. C. Bridges, Jr., Department of Applied Economics and Statistics, Clemson University, Clemson, SC 29634

\begin{abstract}
Meadows, I. M., Zwart, D. C., Jeffers, S. N., Waldrop, T. A., and Bridges, W. C., Jr. 2011. Effects of fuel reduction treatments on incidence of Phytophthora species in soil of a southern Appalachian Mountain forest. Plant Dis. 95:811-820.

The National Fire and Fire Surrogate Study was initiated to study the effects of fuel reduction treatments on forest ecosystems. Four fuel reduction treatments were applied to three sites in a southern Appalachian Mountain forest in western North Carolina: prescribed burning, mechanical fuel reduction, mechanical fuel reduction followed by prescribed burning, and a nontreated control. To determine the effects of fuel reduction treatments on Phytophthora spp. in soil, incidences were assessed once before and twice after fuel reduction treatments were applied. Also, the efficiency of the baiting bioassay used to detect species of Phytophthora was evaluated, and the potential virulence of isolates of Phytophthora spp. collected from forest soils was deter-

mined. Phytophthora cinnamomi and P. heveae were the only two species recovered from the study site. Incidences of these species were not significantly affected by fuel reduction treatments, but incidence of $P$. cinnamomi increased over time. In the baiting bioassay, camellia leaf disks were better than hemlock needles as baits. P. cinnamomi was detected best in fresh soil, whereas $P$. heveae was detected best when soil was air-dried and remoistened prior to baiting. Isolates of $P$. heveae were weakly virulent and, therefore, potentially pathogeniccausing lesions only on wounded mountain laurel and rhododendron leaves; however, isolates of $P$. cinnamomi were virulent and caused root rot and mortality on mountain laurel and white pine plants.
\end{abstract}

Throughout the past century, fire usually has been excluded from forests in the United States due to fire exclusion policies administered by federal and local governments (46). As a result, many fire-adapted forests have accumulated excessive amounts of fuels and, therefore, are at risk to severe wildfires $(4,38,55)$. Mechanical fuel reduction practices (e.g., cutting, thinning, brush removal, mastication) have been used in forests to reduce the accumulation of fuels and to remove undesirable tree and shrub species; however, the effects of these practices on forest ecosystems are not well understood. To address this issue, the National Fire and Fire Surrogate study, funded by the United States Department of the Interior-United States Department of Agriculture Joint Fire Sciences Program and the National Fire Plan, was initiated in 2000 to determine the effects of prescribed fire and other fuel reduction methods on a variety of ecosystem characteristics in forests across the United States (62). There were 13 study sites located throughout the country; the majority of these sites primarily were pine forest ecosystems. However, a study site in the southern Appalachian Mountains was composed predominantly of mixed hardwoods. One of the goals of the Fire and Fire Surrogate study was to determine the effects of fire and other fuel reduction treatments on the incidence of selected root pathogens of forest trees.

Worldwide, there are many species of Phytophthora de Bary that are notorious pathogens of hardwood trees $(17,51)$. In Australia, introduction of Phytophthora cinnamomi Rands has caused extensive mortality of many native tree and understory species in forests across the country $(15,54,63,67)$, and other species of Phytophthora also may be involved (10). In Europe, Phytophthora spp.

Corresponding author: S. N. Jeffers, E-mail: sjffrs@ clemson.edu

Current address of D. C. Zwart: Center for Urban Horticulture, School of Forest Resources, University of Washington, Seattle, WA 98195.

Accepted for publication 22 February 2011.

doi:10.1094/PDIS-07-10-0505

(c) 2011 The American Phytopathological Society have been found to be causal agents of oak decline. This disease occurs in many European countries and is caused by a variety of species of Phytophthora, some of which had not been described previously $(2,3,22,33-36,56)$. Other woodland and landscape trees and shrubs are susceptible to several recently described speciesincluding $P$. alni Brasier \& S.A. Kirk, P. ramorum Werres, De Cock, \& Man in't Veld, and P. kernoviae Brasier, Beales, \& S.A. Kirk (7-9). In Mexico, P. cinnamomi was found to be associated with decline of several native oak species as well as some understory plants $(53,64)$.

In the United States, several species of Phytophthora have been associated with deciduous forest trees. Balci et al. (1) recently reported the occurrence of $P$. cinnamomi and several other species of Phytophthora in oak forests in the eastern and north-central United States. In California, P. cinnamomi was associated with declining cork oak and coast live oak trees and also causes root rot on avocado trees $(44,67)$. Recently, $P$. ramorum has caused extensive mortality of oak and tanoak trees as well as other tree and woody understory plant species in the coastal forests of California and southwestern Oregon $(19,48)$. Research on sudden oak death in California and Oregon has led to the discovery of other previously undescribed species of Phytophthora and species previously not known to occur in this region-e.g., P. nemorosa E.M. Hans. \& Reeser, $P$. pseudosyringae T. Jung \& Delatour, and $P$. siskiyouensis Reeser \& E.M. Hans. $(24,40,47)$.

In the southeastern United States, P. cinnamomi has been established for more than a century $(12,14,21,26,66,67)$ and was responsible for the death of American chestnut trees in the early to mid-1900s $(14,66)$. P. cinnamomi also is the causal agent of littleleaf disease of shortleaf and loblolly pine, which occurs throughout much of the southeastern United States $(11,13)$. Jordan and Tainter (32) reported that several species of oaks common to the southern Appalachian Mountains may be susceptible to P. cinnamomi, although they did not observe disease symptoms in the forest. More recently, P. cinnamomi has been found to cause bleeding cankers on laurel oaks in Florida (65) and in coastal South Carolina (S. N. Jeffers and D. C. Zwart, unpublished). In addition, $P$. cinnamomi is the most common species of Phytophthora attacking woody ornamental crops in nurseries and landscapes in South 
Carolina (S. N. Jeffers, unpublished). In 2002, P. cinnamomi and $P$. heveae A. Thomps. were reported to be present in forest soils in the Jocassee Gorges region of northwestern South Carolina (64). P. heveae has been recovered previously from forest ecosystems in the southeast but only rarely $(12,26,28)$.

Several reports suggest that prescribed fire may reduce the amount of inoculum of species of Phytophthora in forest ecosystems $(15,16,20,23,25,37,39,63)$, although there is no information on the effects of fire or other fuel reduction treatments on Phytophthora spp. in forests of the southeastern United States. Therefore, the objectives of this study were fourfold: to determine the occurrence and distribution of Phytophthora spp. in soil of a hardwood forest site in the southern Appalachian Mountains, to assess the impact of fuel reduction treatments on incidences of these pathogens in forest soils, to evaluate the efficiency of a baiting bioassay for detecting Phytophthora spp. in forest soil, and to determine the potential virulence of the species of Phytophthora found in these forest soils. Several preliminary reports have been published $(42,43,68,69)$.

\section{Materials and Methods}

Study site. The study site was located on the Green River Game Land in Polk Co., NC, which is in the western region of the state on the eastern slope of the Blue Ridge escarpment. A wide variety of cover and site types can be found in the region due to its diverse topography. The forests of the study area were 80 to 120 years old and showed no indication of past agriculture or recent fire; this site has been thoroughly described previously (58). Forest composition was mixed-oak with pitch pine (Pinus rigida Mill.) and Table Mountain pine ( $P$. pungens Lamb.) on xeric ridges and eastern white pine (P. strobus L.) in moist coves. Chestnut oak (Quercus prinus L.), scarlet oak ( $Q$. coccinea Münchh.), white oak ( $Q$. alba L.), northern red oak ( $Q$. rubra L.), and black oak ( $Q$. velutina Lam.) predominated at all sites with other common species including sourwood (Oxydendrum arboreum (L.) DC.), red maple (Acer rubrum L.), yellow-poplar (Liriodendron tulipifera L.), mockernut hickory (Carya tomentosa (Lam.) Nutt.), and blackgum (Nyssa sylvatica Marsh.). Dense growths of ericaceous shrubs-including mountain laurel (Kalmia latifolia L.), rhododendron (Rhododendron maximum L. and $R$. minus Michx.), flame azalea ( $R$. calendulaceum (Michx.) Torr.), and blueberry (Vaccinium spp. L.)—were present throughout the study area. Historically, the forest has had a short-interval, low- to moderate-severity fire regime, but at the time this study was initiated, it had not been burned (natural or prescribed) in 5 years or thinned in 10 years. Overall, trees in the treatment areas of this study appeared healthy and symptoms of decline and dieback were not observed.

Experimental design. Four treatments were used: prescribed burning, mechanical fuel reduction, mechanical fuel reduction followed by prescribed burning, and a nontreated control. The experiment was established as a randomized complete block design with three geographically distinct replicates as blocks and one plot of each treatment (i.e., a treatment area) in each replicate (58). Each treatment area covered a minimum of 14 ha, which included buffer zones. A $50 \times 50$-m grid was established in each treatment area with 36 to 40 grid points marked with metal rods and georeferenced. Ten sample plots of 0.1 ha $(50 \times 20 \mathrm{~m})$ were established within each treatment area, and each sample plot was further divided into 10 subplots $(10 \times 10 \mathrm{~m}$ each $)$. Sample plots were located at selected grid intersections and were oriented along gridlines. The variable measured in each sample plot was incidence of Phytophthora spp. in a composite soil sample (see description below).

Treatment application. In mechanical fuel reduction treatment areas, all mountain laurel and rhododendron shrubs and all trees taller than $2 \mathrm{~m}$ and less than $10 \mathrm{~cm}$ in diameter at breast height were felled. Mechanical fuel reduction was conducted in December 2001 through March 2002 by contract operators with chainsaws. No fuels were removed from the site. In treatment areas where mechanical fuel reduction was followed by burning, fuels were allowed to dry and partially decompose for 1 year following mechanical fuel reduction before prescribed fire was applied. The prescribed fire treatment areas were burned in March 2003 and again in February and March 2006. In both burns, fire intensity was low to moderate with flame heights generally less than $1 \mathrm{~m}$. The objective of all fires was to reduce the woody shrub and fuel component to minimize damage from potential wildfires (57).

Soil sample collection. Soil samples were collected during three sample periods: before treatments were applied in December 2001 to February 2002 and twice after treatments had been applied-in November 2003 to February 2004, after the first burn, and in January to March 2007, after the second burn. Sample periods will be referred to by the year in which they predominantly occurred-i.e., 2002, 2004, and 2007. From each of the 10 sample plots within a treatment area, 20 soil cores (each $2.5 \mathrm{~cm}$ in diameter $\times 20 \mathrm{~cm}$ deep) were collected arbitrarily (two soil cores from each of the 10 subplots) using an Oakfield soil sampling tube (Forestry Suppliers, Inc.). Soil cores were combined in a plastic bag to produce a 1- to 2-liter composite sample that was representative of each sample plot. Soil samples were stored in the dark at room temperature (22 to $24^{\circ} \mathrm{C}$ ) until assayed.

Isolation of Phytophthora spp. To detect species of Phytophthora in soil samples, a baiting bioassay was used that previously was developed and validated in our laboratory $(18,64)$. Each soil sample was passed through a 2 -mm-mesh sieve to remove large debris and then was mixed thoroughly. For the 2002 and 2004 sample periods, six 100-ml aliquots were assayed from each soil sample. Each aliquot was placed in a 470-ml freezer box (Arrow Plastic Manufacturing Co.). Three aliquots of fresh soil were assayed by flooding each with $200 \mathrm{ml}$ of distilled water and then adding leaf-piece baits. The other three aliquots of soil were airdried for 3 days at room temperature and then remoistened to near saturation with distilled water, and boxes were covered. Remoistened aliquots were held for an additional 3 days at room temperature, and then soil aliquots were flooded with $200 \mathrm{ml}$ of distilled water and baits were added. Eight eastern hemlock (Tsuga canadensis (L.) Carrière) needles and eight camellia (Camellia japonica L. 'Governor Mouton') leaf disks (5 mm diameter) were floated on the surface of the water as baits. Three baits of each type were removed at 24 and $72 \mathrm{~h}$, blotted dry, and embedded in PARPH-V8, a medium selective for species of Phytophthora $(18,30)$-recipe below. For the 2007 sample period, the baiting regime was modified based on results observed in 2002 and 2004: three fresh soil aliquots were assayed, only camellia leaf disks were used as baits, and baits were exposed for $72 \mathrm{~h}$.

For all soil samples, isolation plates were placed in the dark at $20^{\circ} \mathrm{C}$ and were examined regularly for up to 14 days for typical colonies of Phytophthora spp. The numbers of baits from which Phytophthora spp. grew were counted. Representative colonies of Phytophthora spp. were subcultured on PARPH-V8 and stored on corn meal agar in 8 -ml glass vials at $15^{\circ} \mathrm{C}$ in the dark.

PARPH-V8 selective medium contained (per liter): $950 \mathrm{ml}$ of distilled water, $50 \mathrm{ml}$ of buffered and clarified V8 Juice (Campbell Soup Company), $15 \mathrm{~g}$ of Difco Bacto agar (Becton Dickinson and Company), $5 \mathrm{mg}$ of pimaricin (as Delvocid Instant; Gist-Brocades), $250 \mathrm{mg}$ of ampicillin sodium salt (Sigma-Aldrich Co.), 10 $\mathrm{mg}$ of rifamycin-SV sodium salt (Sigma), $50 \mathrm{mg}$ of PCNB (as Terraclor; Crompton Uniroyal Chemical), and $50 \mathrm{mg}$ of hymexazol (as Tachigaren; Gustafson LLC.). Each amendment was dissolved or suspended in $5 \mathrm{ml}$ of sterile distilled water and then was added individually to molten medium $\left(50^{\circ} \mathrm{C}\right)$ after autoclaving. Buffered and clarified V8 Juice was prepared by thoroughly mixing $1 \mathrm{~g}$ of $\mathrm{CaCO}_{3}$ with each $100 \mathrm{ml}$ of V8 Juice, and then this mixture was centrifuged at $7,970 \times g(7,000 \mathrm{rpm})$ for $10 \mathrm{~min}$; the clarified supernatant was collected and frozen until used.

Identification of Phytophthora spp. Representative isolates of Phytophthora spp. collected during the 2002 and 2004 sample periods were identified based on standard morphological and physiological characteristics $(17,52,60,61)$-including production and size of sexual and asexual propagules, mating type, and colony 
morphology. To produce sporangia, isolates were grown on $10 \%$ V8 agar $(900 \mathrm{ml}$ of distilled water, $100 \mathrm{ml}$ of V8 Juice, $1 \mathrm{~g}$ of $\mathrm{CaCO}_{3}$, and $15 \mathrm{~g}$ of Bacto Agar) at $20^{\circ} \mathrm{C}$ for 4 to 7 days in the dark. Agar plugs from the advancing edge of the colony were placed in $60-\mathrm{mm}$-diameter petri plates and covered with $1.5 \%$ nonsterile soil extract solution (29). Plates were placed under continuous fluorescent light at room temperature for 24 to $48 \mathrm{~h}$, and sporangia were observed and measured $(\times 200$ to 400$)$ to determine length:width ratios.

To produce oospores, isolates were grown on super-clarified V8 juice agar (scV8A) (29) at $25^{\circ} \mathrm{C}$ in the dark for 2 to 4 weeks. One liter of scV8A contained: $100 \mathrm{ml}$ of buffered and clarified V8 Juice, $30 \mathrm{mg}$ of $\beta$-sitosterol (dissolved in $10 \mathrm{ml}$ of $95 \%$ ethanol), $20 \mathrm{mg}$ of L-tryptophan, $100 \mathrm{mg}$ of $\mathrm{CaCl}_{2} \cdot 2 \mathrm{H}_{2} \mathrm{O}, 1 \mathrm{mg}$ of thiamine $\mathrm{HCl}, 15 \mathrm{~g}$ of Bacto Agar, and $900 \mathrm{ml}$ of distilled water. For isolates of $P$. cinnamomi, which is heterothallic $(52,59,61,67)$, each isolate was paired with standard A1 (SC.99-2589) and A2 (SC.96-1306) isolates on scV8A in 24-well, flat-bottomed tissue culture plates (Costar 3524; VWR International, Inc.); each well contained $1 \mathrm{ml}$ of scV8A medium. Agar plugs (1.5 mm diameter) from a standard isolate and one of the forest soil isolates were placed on opposite sides of a well (i.e., two wells per isolate). Cultures were incubated at $25^{\circ} \mathrm{C}$ in the dark for 2 to 4 weeks and examined weekly for oospores. Isolates that consistently formed oospores with the A1 standard were designated A2 mating type, and those that consistently formed oospores with the A2 standard were designated A1 mating type. All pairings were conducted twice.

Potential virulence of $\boldsymbol{P}$. heveae. The potential virulence of three isolates of $P$. heveae (R2T2, R1C6, and R3B30) recovered during this study was evaluated using wounded and nonwounded leaves of both native and ornamental plant species: Rhododendron maximum, $R$. catawbiense Michx. 'English Roseum', and Kalmia latifolia 'Peppermint'. Leaves of $R$. catawbiense and $K$. latifolia were collected from plants growing in a greenhouse, and leaves of $R$. maximum were collected from native plants growing in northwestern South Carolina. Leaves were removed from healthy plants, placed in moist chambers, and inoculated by placing 2-mm-diameter PARPH-V8 agar plugs (taken from the margins of actively growing colonies) onto the abaxial surface of the leaves, approximately midway between the midvein and the leaf margin. To inoculate leaves of Rhododendron spp., one plug of each isolate was placed on one side of the leaf midvein on top of a wound made with a sterile dissecting needle, and one plug of each isolate was placed on the nonwounded side of the leaf. This was replicated on six leaves of each species of rhododendron, and the experiment was conducted twice.

Inoculation of $K$. latifolia leaves was different due to the smaller size of leaves. With this species, each leaf was inoculated with only one isolate; one side of the abaxial surface of the leaf was wounded and one side was left intact. Five replicate leaves were inoculated with each isolate (15 leaves total), and the experiment was conducted twice. All moist chambers were placed at $20^{\circ} \mathrm{C}$ for 5 days, and lesion diameters were calculated by averaging two measurements of each lesion.

Potential virulence of $\boldsymbol{P}$. cinnamomi. Eleven isolates of $P$. cinnamomi representative of those recovered from soils before treatments were applied were used to determine virulence of forest isolates on both native and ornamental plants under conditions conducive to disease development. For comparison, three isolates recovered from roots of diseased nursery plants (one each from Leyland cypress, mountain laurel, and white pine) also were tested. Two plant species native to the southern Appalachian Mountain region, mountain laurel (Kalmia latifolia) and white pine (Pinus strobus), and two plant species commonly grown in ornamental plant nurseries, Sawara cypress (Chamaecyparis pisifera (Siebold \& Zucc.) Endl. 'Golden Mop') and Leyland cypress ( $\times$ Cuprocyparis leylandii (A.B. Jacks. \& Dallim.) Farjon = $\times$ Cupressocyparis leylandii (A.B. Jacks \& Dallim.) Dallim.), were inoculated. K. latifolia 'Peppermint' was used as a fair representation of native mountain laurel. Plants were assayed for incipient infection by Phytophthora spp. before being used. One-year-old white pine seedlings were transplanted into a soilless container mix (Fafard 3B; Fafard, Inc.) in 260-ml planting cones (Deepot Cells; Stuewe \& Sons, Inc.). The other three plant species were transplanted into container mix in 400-ml plastic pots. Plants were grown in a greenhouse (average daily temperature 20 to $26^{\circ} \mathrm{C}$ ) for several weeks to become established prior to inoculation. Plants were fertilized weekly with a complete fertilizer (10-10-10; N-P-K).

Inoculum of $P$. cinnamomi was produced on sterilized rice grains (27): $18 \mathrm{ml}$ of distilled water was added to $25 \mathrm{~g}$ of long-grain white rice in 250-ml Erlenmeyer flasks; flasks were autoclaved for 30 min on 1 day and then autoclaved again the next day for $40 \mathrm{~min}$. After sterilizing, three PARPH-V8 agar plugs taken from the margin of an actively growing colony were added to the rice, and flasks were placed in the dark at $25^{\circ} \mathrm{C}$. Flasks were shaken gently each day to ensure uniform colonization of the rice grains, and inocula were incubated for 14 days. Three colonized rice grains were added to each $400-\mathrm{ml}$ pot around the perimeter of the root ball to a depth of $5 \mathrm{~cm}$. White pine seedlings were inoculated with two rice grains per cone. Plants were watered immediately following inoculation.

For each of the 11 isolates from forest soils, three white pine seedlings, four Leyland cypress plants, and five plants each of mountain laurel and Sawara cypress were inoculated; equal numbers of plants of each species were not inoculated and served as controls. The three nursery isolates served as positive controls to validate the inoculation procedure. Therefore, only plant species from which the isolate was recovered were inoculated-i.e., three white pine seedlings were inoculated with the isolate from white pine, five mountain laurel plants were inoculated with the isolate from mountain laurel, and four Leyland cypress and five Sawara cypress plants were inoculated with the isolate from Leyland cypress (an isolate from Sawara cypress was not available). The experiment was conducted twice.

After inoculation, all plants were grown in a greenhouse for 18 weeks and watered daily to maintain conditions conducive for disease development. For the first 6 weeks, in addition to daily watering, plants were flooded once a week for $24 \mathrm{~h}$ to further encourage root rot development. Plants then were grown for another 12 weeks with just daily watering before final evaluation of plant mortality. Plant health and symptom development were monitored regularly throughout the experiment. Dead plants were removed and roots pieces were placed on PARPH-V8 to attempt to isolate $P$. cinnamomi.

Statistical analyses. All statistical analyses were conducted using SAS for Windows, ver. 9.1, statistical software (SAS Institute, Inc.). The type I error rate $(\alpha)$ was set at 0.05 for all analyses. Data on recovery of Phytophthora spp. by soil baiting were summarized as the numbers of baits and bait boxes with species of Phytophthora present. To determine the effects of fuel reduction treatments, proportions of soil subsamples (i.e., aliquots) and sample plots in a treatment area with Phytophthora spp. present were calculated and used as the response variables. The analysis was conducted in two parts. In the first part, a 2-way analysis of variance (ANOVA) was used to evaluate treatments and sample period. When an experimental factor was determined to be significant in the ANOVA, means were separated by orthogonal linear contrasts. In the second part, the consistency of occurrence of Phytophthora spp. in sample plots between pairs of sample periods (i.e., occurrence in the same sample plot at different sample times) was determined using 2-way contingency tables and calculating Cohen's Kappa Coefficient $(K)$ - a measure of correlation for presence-absence data where $K$ $=0$ signifies no correlation and $K=1$ signifies complete correlation. To test the efficiency of the baiting bioassay, a 3-way ANOVA was used to evaluate bait type, baiting duration, and soil treatment (i.e., fresh versus air-dried soil). Fisher's protected least significant difference (LSD) was used to compare pairs of means when an experimental factor was significant.

In the experiment testing potential virulence of $P$. heveae, mean lesion diameters produced by isolates of $P$. heveae on wounded and 
nonwounded leaves were analyzed using 2-way ANOVA with isolate and plant species as factors. Specific means were compared by LSD. In the experiment testing the virulence of $P$. cinnamomi, the percentages of plants killed by each isolate were determined for each plant species, and significant differences in mortality among all 13 treatments (i.e., 12 isolates and the control) and among the 12 isolates for each plant species were determined by chi-square (12 and 11 degrees of freedom, respectively).

\section{Results}

Identification of representative isolates. Two species of Phytophthora were recovered in this study: $P$. cinnamomi and $P$. heveae. Twelve isolates of $P$. cinnamomi were examined-one from each treatment area. These isolates all had typical morphological and physiological characteristics of this species $(17,52,60,61,67)$. Colony morphology on PARPH-V8 medium was uniform and lacked any distinct pattern. Isolates produced distinctive, coralloid mycelia with numerous hypha swellings in the agar, aerial mycelia above the agar surface, and abundant clusters of botryose chlamydospores. All isolates tested were heterothallic and A2 mating type; oospores were not produced in single-isolate cultures and were only produced when paired with the standard A1 isolate. Oogonia were spherical with a smooth wall and hyaline, and oospores were nearly plerotic. Antheridia were amphigynous and frequently bicellular; 2-celled antheridia were observed for all isolates. Mean oospore diameters ranged from 34.5 to $37.0 \mu \mathrm{m}$ for individual isolates with an average diameter of $35.8 \mu \mathrm{m}$ for all isolates, and mean oogonium diameters ranged from 37.9 to 40.7 $\mu \mathrm{m}$ for individual isolates with an average diameter of $39.1 \mu \mathrm{m}$ for all isolates. Sporangia were produced on simple sporangiophores; they were non-papillate, internally proliferating, and had an average length-to-width ratio of 1.38 (range 1.33 to 1.43 ).

Three isolates of $P$. heveae were examined-one from each infested sample plot in 2002; they all produced uniform, appressed colonies on PARPH-V8 medium. Isolates produced relatively fine hyphae and abundant oospores on most media; chlamydospores were not observed. All isolates examined were homothallic. Oogonia were spherical, hyaline, and smooth-walled, and they had characteristic funnel-shaped, tapered bases $(17,52)$. Oospores were aplerotic, and antheridia were amphigynous and single-celled. Sporangia formed only infrequently in nonsterile soil extract solution; these were papillate and formed on irregular sporangiophores. One representative isolate of each species from each sample plot in each sample period was saved and incorporated into the permanent collection of Phytophthora spp. maintained by S. N. Jeffers at Clemson University.

Treatment effects. Overall, the objective for applying the three fuel reduction treatments (prescribed burning, mechanical fuel reduction, mechanical fuel reduction followed by prescribed burning)-i.e., minimizing the risk of potential wildfires-was met
(58). The burn treatment created some overstory mortality, but stand basal area was reduced only slightly as surviving trees continued to grow. Forbs and grasses increased in response to burning, and the treatment areas where mechanical fuel reduction was followed by burning contained the greatest abundance of these plant types. Tree regeneration was abundant; two prescribed burns seemed to favor oak regeneration by severely reducing the density of red maple and yellow-poplar. The mechanical fuel reduction treatment (i.e., felling trees and shrubs with chainsaws) essentially removed the entire sapling and shrub layer and had no impact on overstory density. Cut trees and shrubs resprouted, and this regeneration began growing back into the understory and midstory layer. The herbaceous vegetation on the forest floor was unaffected by the mechanical fuel reduction treatment, but there was a slight increase in oak regeneration. The treatment of mechanical fuel reduction followed by burning produced the greatest changes in stand structure. Hot fires resulted from the burning of dried, cut shrubs and produced the most open stands of any treatment; therefore, vegetation that developed on the forest floor had an increase in numbers of woody species, forbs, and grasses.

Before fuel reduction treatments were applied, Phytophthora spp. were found in 35\% (42/120) of sample plots (Fig. 1). After fuel reduction treatments were applied, Phytophthora spp. were found in 33\% (40/120) of sample plots during the 2004 sample period and in 59\% (71/120) of sample plots during the 2007 sample period (Fig. 1). Incidence of $P$. heveae remained constant throughout the study; it was detected in only three of 120 sample plots in each sample period and in the same two sample plots during all three sample periods (Fig. 1). The incidence of $P$. cinnamomi, however, changed over time. It was found in 33\% (40/120) of sample plots in 2002, in 31\% (37/120) of sample plots in 2004, and in 57\% (68/120) of sample plots in 2007 (Fig. 1). Incidences of Phytophthora spp. within individual treatment areas ranged from 20 to $60 \%$ in 2002,0 to $80 \%$ in 2004 , and 20 to $100 \%$ in 2007 (Fig. 1). Mean incidences before treatments were applied in 2002 ranged from 14.4 to $38.9 \%$ in soil subsamples and 23.3 to $43.3 \%$ in sample plots (Fig. 2). Mean incidences after treatments were applied in 2004 ranged from 14.4 to $34.4 \%$ in soil subsamples and 20 to $40 \%$ in sample plots (Fig. 2). After the second prescribed fire, mean incidence levels in 2007 ranged from 42.2 to $67.8 \%$ in soil subsamples and 50 to $76.7 \%$ in sample plots (Fig. 2).

In a 2-way ANOVA of all incidence data (Table 1), interactions were not significant, so the main effects of treatment, sample period, and block could be examined. There was no significant effect of treatment on incidence of Phytophthora spp. in sample plots $(P$ $=0.253)$ or soil subsamples $(P=0.123)$-i.e., incidences among treatments were similar for all three sample periods combined. However, there was a significant sample period effect both in sample plots $(P<0.001)$ and in soil subsamples $(P=0.002)$. There also was a significant block effect based on incidences in both

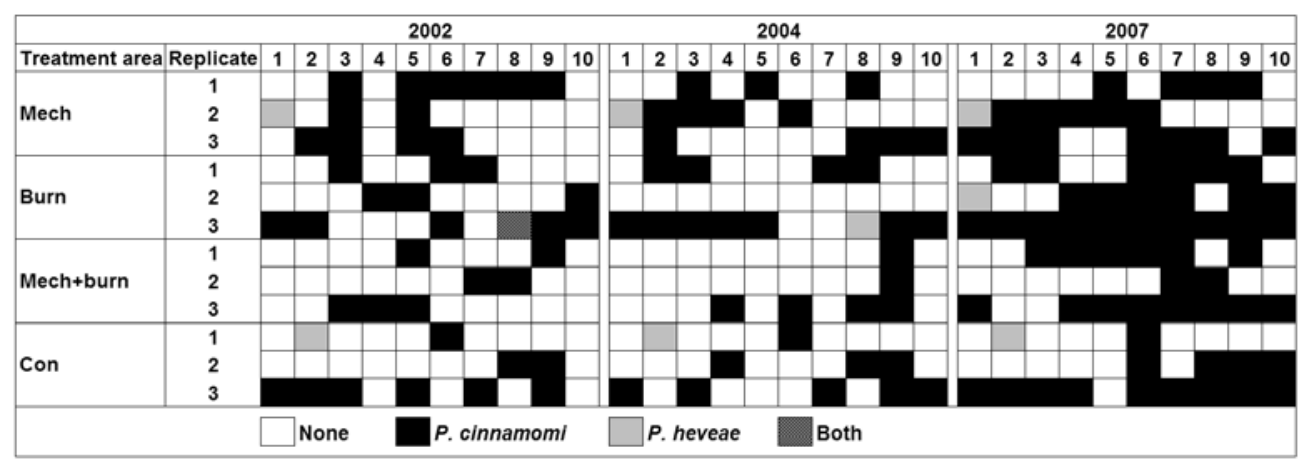

Fig. 1. Diagrammatic representation of the sample plots in which Phytophthora cinnamomi and $P$. heveae were detected before (2002) and after (2004 and 2007) fuel reduction treatments were applied to treatment areas in a hardwood forest in western North Carolina. Four treatments were assigned to areas in three replicates: mechanical fuel reduction (mech) - conducted once in December 2001 through March 2002; prescribed burning (burn) - conducted twice in March 2003 and again in February through March 2006; mechanical fuel reduction followed by prescribed burning (mech+burn); and a nontreated control (con). Soil samples were collected from 10 sample plots in each of the 12 treatment areas, and Phytophthora spp. were detected with a baiting bioassay. 
sample plots $(P<0.001)$ and soil subsamples $(P=0.001)$. Therefore, geographic location of replicates had a significant effect on incidence of Phytophthora spp., and blocking reduced this source of variance.

Orthogonal linear contrasts were used to determine where differences among sample periods occurred. Incidence levels before (2002) fuel reduction treatments were applied were significantly
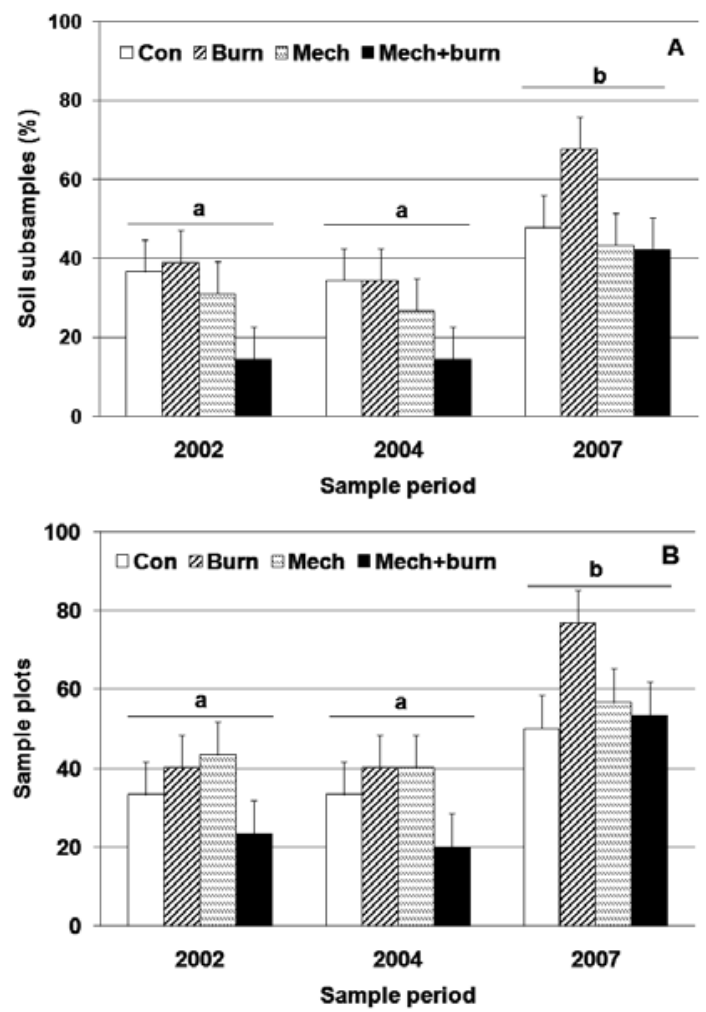

Fig. 2. Mean incidences of Phytophthora spp. in treatment areas based on $\mathbf{A}$, percentages of 30 soil subsamples, and $\mathbf{B}$, percentages of 10 sample plots that were infested before (2002) and after (2004 and 2007) four fuel reduction treatments (prescribed burning [burn], mechanical fuel reduction [mech], mechanical fuel reduction followed by burning [mech+burn], and a nontreated control [con]) were applied to treatment areas in three geographically separated replicates at the Green River Game Land study site. Error bars equal one standard deviation. Sample periods with the same letter above treatment means are not significantly different (Fisher's protected least significant difference, $\alpha=0.05$ ). less than those occurring after $(2004+2007)$ treatment applications in sample plots $(P=0.046)$ but not in soil subsamples $(P=$ 0.105) (Table 1, Fig. 2). However, there also was a significant difference in incidence levels between 2004 and 2007 in both sample plots $(P<0.001)$ and soil subsamples $(P=0.001)$, with incidences greater in 2007 than in 2004. Incidence levels in 2002 and 2004 combined were significantly less than those in 2007 in sample plots $(P<0.001)$ and soil subsamples $(P<0.001)$, and incidence in 2002 was not significantly different than that in 2004 in either sample plots $(P=0.785)$ or soil subsamples $(P=$ 0.638).

Consistency of occurrence of Phytophthora spp. Based on Cohen's Kappa coefficient, detection consistency was similar in the control and burn treatment areas for all sample periods, i.e., Phytophthora spp. consistently were found in the same sample plots during all three sample periods (Table 2). However, in the mechanical and mechanical + burn treatment areas, there was a significant difference in the sample plots from which Phytophthora species were detected between the 2002 and 2004 sample periods ( $K=0.11$ and $K=0.12$, respectively). For all four treatments, consistency in detection varied from 17 to 26 sample plots $(K=0.11$ to $K=0.70$ ) between sample periods 2002 and 2004, from 18 to 23 sample plots $(K=0.23$ to $K=0.53)$ between 2004 and 2007, and from 19 to 25 sample plots ( $K=0.29$ to $K=0.67$ ) between 2002 and 2007.

Efficiency of the baiting bioassay. The efficiency of the bioassay used to detect $P$. cinnamomi and $P$. heveae was determined using soil samples collected both before (2002) and after (2004) treatments were applied. The first step in the analysis involved testing for a treatment by year interaction. This interaction was not significant; therefore, results from both years were combined for the remaining analyses (Table 3 ). When the three parameters of the baiting bioassay were evaluated by 3 -way ANOVA, the only interaction that was significant was bait type $\times$ soil treatment $(P<$ $0.001)$ for detection of $P$. cinnamomi. The main effects of both bait type and soil treatment also were significant $(P<0.001)$ for detection of this species, but baiting duration did not significantly affect detection $(P=0.161)$, i.e., detection of $P$. cinnamomi by baits floated for $24 \mathrm{~h}$ was as effective as those floated for $72 \mathrm{~h}$. Therefore, the individual means for each bait type $\times$ soil treatment combination were compared. Detection of $P$. cinnamomi was greatest when camellia leaf disks were used to bait fresh soil, and detection of this species in air-dried soil was significantly less than detection in fresh soil regardless of bait type (Table 3). All three baiting parameters significantly affected detection of $P$. heveae in forest soils (Table 3). Detection was better in air-dried soil, with

Table 1. Two-way analysis of variance (ANOVA) of proportions of sample plots and soil subsamples in which Phytophthora spp. were detected before (2002) and after (2004 and 2007) fuel reduction treatments were applied to areas in a hardwood forest in western North Carolinaw

\begin{tabular}{|c|c|c|c|c|c|c|}
\hline \multirow[b]{2}{*}{ Source } & \multicolumn{3}{|c|}{ Sample plots ${ }^{x}$} & \multicolumn{3}{|c|}{ Soil subsamples $^{x}$} \\
\hline & df & $F$ & $P>F^{y}$ & df & $F$ & $P>F^{y}$ \\
\hline Treatment & 3 & 1.77 & 0.253 & 3 & 2.90 & 0.123 \\
\hline Sample period & 2 & 11.58 & $<0.001$ & 2 & 9.24 & 0.002 \\
\hline Replicate & 2 & 15.35 & $<0.001$ & 2 & 11.05 & 0.001 \\
\hline Treatment $\times$ replicate & 6 & 1.81 & 0.161 & 6 & 1.47 & 0.252 \\
\hline Treatment $\times$ sample period & 6 & 0.55 & 0.762 & 6 & 0.52 & 0.788 \\
\hline \multicolumn{7}{|l|}{ Orthogonal contrasts ${ }^{\mathrm{z}}$} \\
\hline 2002 vs. $(2004+2007)$ & 1 & 2.16 & 0.046 & 1 & 1.72 & 0.105 \\
\hline 2004 vs. 2007 & 1 & 4.30 & $<0.001$ & 1 & 3.94 & 0.001 \\
\hline$(2002+2004)$ vs. 2007 & 1 & 4.80 & $<0.001$ & 1 & 4.27 & $<0.001$ \\
\hline 2002 vs. 2004 & 1 & 0.28 & 0.785 & 1 & 0.48 & 0.638 \\
\hline
\end{tabular}

${ }^{\text {w}}$ Four fuel reduction treatments were assigned to three replicates in different locations: mechanical fuel reduction, conducted once in December 2001 through March 2002; prescribed burning, conducted twice in March 2003 and again in February through March 2006; mechanical fuel reduction followed by burning; and a nontreated control.

x At each sample period, soil was collected from 10 sample plots in each of the 12 treatment areas; three soil subsamples then were assayed from each sample plot.

y Probability of a greater $F$ value occurring; $P$ values were judged significant at $\alpha=0.05$.

${ }^{\mathrm{z}}$ Two sets of single-degree-of-freedom orthogonal linear contrasts comparing sample periods: before versus after treatment areas had mechanical fuel reduction once and were burned twice (2002 vs. [2004 + 2007]) and before and after treatment areas had mechanical fuel reduction and were burned once versus after treatment areas were burned a second time ([2002 + 2004] vs. 2007). 
camellia leaf disks, and after $72 \mathrm{~h}$; however, $P$. heveae also was detected with hemlock needles, after only $24 \mathrm{~h}$, and in fresh soil.

Potential virulence of $\boldsymbol{P}$. heveae. The first part of the analysis was to determine if there was a trial by treatment interaction; this interaction was not significant, so data from the two trials were combined for the remaining analyses. None of the three isolates of $P$. heveae caused lesions on nonwounded leaves, but all three isolates of $P$. heveae produced lesions on wounded leaves of $R$. maximum, $R$. catawbiense 'English Roseum', and $K$. latifolia 'Peppermint' (Fig. 3). There was a significant isolate $\times$ plant species interaction $(P=0.015)$, indicating that the isolates behaved differently on the three plant species. Overall, there were significant differences in lesion diameters produced on different plant species $(P<0.001)$ and in lesion diameters produced by the different isolates of $P$. heveae $(P<0.007)$. For all isolates of $P$. heveae combined, mean lesion diameter on leaves was greatest on $R$. catawbiense $(13.0 \mathrm{~mm})$, intermediate on $R$. maximum $(6.5 \mathrm{~mm})$, and least on $K$. latifolia $(3.2 \mathrm{~mm})$ (Fig. 3). Across all three plant species, isolate R1C6 produced significantly $(P<0.001)$ greater lesions $(9.2 \mathrm{~mm})$ than both isolate R2T2 $(6.4 \mathrm{~mm})$ and isolate R3B30 (7.1 $\mathrm{mm})$.

On leaves of $K$. latifolia, isolate R1C6 produced significantly larger lesions than isolate R3B30 $(P=0.021)$ (Fig 3). On leaves of $R$. maximum, isolate R1C6 produced lesions that were significantly larger than those produced by either isolate R2T2 or isolate $\mathrm{R} 3 \mathrm{~B} 30$, and isolate $\mathrm{R} 3 \mathrm{~B} 30$ produced lesions that were significantly larger than those produced by isolate R2T2 (Fig. 3). On leaves of $R$. catawbiense, there was no significant difference among lesion sizes produced by the three isolates; this plant species clearly was the most readily colonized by the isolates of $P$. heveae tested in this study (Fig. 3).

Potential virulence of $\boldsymbol{P}$. cinnamomi. In a preliminary analysis, there was not a significant trial by treatment interaction, so data for the two trials were combined for the remaining analyses (Table 4). Plants of all species that were not inoculated grew well and remained free of symptoms throughout the duration of this experiment, except for two white pine seedlings (one in each trial) and one mountain laurel plant that died; however, $P$. cinnamomi was not isolated from these plants, so mortality was assumed to be zero in the analyses. All 12 isolates of $P$. cinnamomi (11 forest soil isolates and the host isolate) killed mountain laurel plants, and mortality caused by the different isolates ranged from 80 to $100 \%$. There was a significant difference $(P<0.001)$ among isolates and the noninoculated control in percentages of plants killed, but there was no difference $(P=0.764)$ among the 12 isolates in the percentages of plants killed. All 12 isolates also killed white pine seedlings. Mortality ranged from 66 to $100 \%$, and these percentages differed significantly $(P=0.004)$ from that in the noninoculated control treatment; there was no difference $(P=0.0567)$ among isolates in mortality to white pine seedlings. Sawara cypress and Leyland cypress plants apparently were not susceptible to $P$. cinnamomi in this experiment; only one or two Sawara cypress plants were killed

Table 2. Comparisons between all pairs of sample periods of the numbers of sample plots in treatment areas with consistent results from a baiting bioassay for detection of Phytophthora species ${ }^{\mathrm{x}}$

\begin{tabular}{|c|c|c|c|c|c|c|}
\hline \multirow[b]{2}{*}{ Treatment ${ }^{y}$} & \multicolumn{2}{|c|}{2002 and 2004} & \multicolumn{2}{|c|}{2004 and 2007} & \multicolumn{2}{|c|}{2002 and 2007} \\
\hline & Number & $K^{z}$ & Number & K & Number & $\boldsymbol{K}$ \\
\hline $\operatorname{Mech}(n=30)$ & 17 & $0.11^{*}$ & 21 & 0.42 & 20 & 0.35 \\
\hline Burn $(n=30)$ & 20 & 0.31 & 19 & 0.34 & 19 & 0.34 \\
\hline Mech + burn $(n=30)$ & 21 & $0.12 *$ & 18 & 0.23 & 19 & 0.29 \\
\hline Control $(n=30)$ & 26 & 0.70 & 23 & 0.53 & 25 & 0.67 \\
\hline Total $(n=120)$ & 84 & 0.33 & 81 & 0.39 & 83 & 0.42 \\
\hline
\end{tabular}

${ }^{\mathrm{x}}$ Soil samples were collected in three different years from 10 sample plots within each treatment area in a hardwood forest in western North Carolina: 2002 , before treatments were applied; 2004, after plots had mechanical fuel reduction and were burned one time; and 2007, after the second burn.

${ }^{y}$ Four fuel reduction treatment areas were assigned to three replicates in different locations: mechanical fuel reduction (mech), conducted in December 2001 through March 2002; prescribed burning (burn), conducted in March 2003 and again in February through March 2006; mechanical fuel reduction followed by burning (mech + burn); and a nontreated control.

${ }^{\mathrm{z}}$ Differences between sample periods were determined using $2 \times 2$ contingency tables and the Kappa Test for Agreement $(\alpha=0.05)$; * Kappa coefficient $(K)$ was not significantly different from zero signifying no correlation in number of sample plots in which Phytophthora spp. were detected for each pair of sample periods.

Table 3. Effects of three baiting bioassay parameters (bait type, baiting duration, and soil treatment) on detection of two species of Phytophthora in forest soil samples collected at the Green River Game Land study site ${ }^{\mathrm{x}}$

\begin{tabular}{|c|c|c|c|c|c|}
\hline \multicolumn{3}{|c|}{ P. cinnamomi } & \multicolumn{3}{|c|}{ P. heveae } \\
\hline Soil treatment & Bait type & Baits colonized $(\%)^{y}$ & Baiting parameter & Parameter factor & Baits colonized $(\%)^{\mathrm{y}}$ \\
\hline \multirow[t]{2}{*}{ Fresh } & Camellia & $22.5 \mathrm{a}$ & Duration & $24 \mathrm{~h}$ & $0.6 \mathrm{~b}$ \\
\hline & Hemlock & $8.8 \mathrm{~b}$ & & $72 \mathrm{~h}$ & $1.0 \mathrm{a}$ \\
\hline \multirow[t]{4}{*}{ Air dried } & Camellia & $3.6 \mathrm{c}$ & Bait type & Camellia & $1.0 \mathrm{a}$ \\
\hline & Hemlock & $1.3 \mathrm{c}$ & & Hemlock & $0.6 \mathrm{~b}$ \\
\hline & & & Soil treatment & Fresh & $0.6 \mathrm{~b}$ \\
\hline & & & & Air dried & $1.0 \mathrm{a}$ \\
\hline \multicolumn{2}{|c|}{ ANOVA: $P>F^{\mathrm{z}}$} & \multicolumn{2}{|c|}{ P. cinnamomi } & \multicolumn{2}{|c|}{ P. heveae } \\
\hline \multicolumn{2}{|l|}{ Duration } & \multicolumn{2}{|c|}{0.161} & \multicolumn{2}{|c|}{0.030} \\
\hline \multicolumn{2}{|l|}{ Bait type } & \multicolumn{2}{|c|}{$<0.001$} & \multicolumn{2}{|c|}{0.030} \\
\hline \multicolumn{2}{|l|}{ Soil treatment } & \multicolumn{2}{|c|}{$<0.001$} & \multicolumn{2}{|c|}{0.030} \\
\hline \multirow{2}{*}{\multicolumn{2}{|c|}{ Duration $\times$ bait type }} & \multirow{2}{*}{\multicolumn{2}{|c|}{$\begin{array}{l}0.943 \\
0.083\end{array}$}} & \multicolumn{2}{|c|}{0.487} \\
\hline & Duration $\times$ soil treatment & & & \multicolumn{2}{|c|}{0.889} \\
\hline \multicolumn{2}{|c|}{ Bait type $\times$ soil treatment } & \multicolumn{2}{|c|}{$\begin{array}{r}0.083 \\
<0.001\end{array}$} & \multicolumn{2}{|c|}{0.676} \\
\hline \multicolumn{2}{|c|}{ Bait type $\times$ duration $\times$ soil treatment } & \multicolumn{2}{|c|}{0.830} & \multicolumn{2}{|c|}{0.781} \\
\hline
\end{tabular}

${ }^{\mathrm{x}}$ Soil samples were collected before and after fuel reduction treatments were applied to treatment areas in three replicates at the study site. For each soil sample collected in 2002 and 2004, three subsamples were baited fresh and after air-drying and remoistening with two types of baits (camellia leaf disks and hemlock needles, six of each per subsample). Three baits of each type were removed at 24 and $72 \mathrm{~h}$ and placed on a selective medium.

${ }^{y}$ Means followed by the same letter are not significantly different (Fisher's protected least significant difference, $\alpha=0.05$ ). For $P$. heveae, pairs of means were compared for each baiting parameter.

${ }^{\text {z }} P$ values of $F$ statistics for the three main effects and all possible interactions from a 3-way analysis of variance (ANOVA). 
by four isolates of $P$. cinnamomi, and no Leyland cypress plants were killed. P. cinnamomi was recovered from all inoculated plants that died.

\section{Discussion}

Information on the incidence and diversity of species of Phytophthora present in the study area needed to be determined and monitored so the effects of fuel reduction treatments could be effectively evaluated. The only species of Phytophthora recovered from the hardwood forest soils collected throughout this study were $P$. cinnamomi and $P$. heveae. This is consistent with other surveys of species of Phytophthora present in forest soils conducted around the world, where usually only one or two species were isolated at a specific site, although the individual species detected varied among the sites sampled $(1,2,3,22,33,56,64)$. All isolates of $P$. cinnamomi collected in the 2002 and 2004 sample periods were the A2 mating type, which is the predominant mating type found in North America (17,67). P. cinnamomi has been recovered numerous times from the southern Appalachian Mountains region over a long period of time $(11-14,26,64)$, and more recently, it has been recovered from soils in hardwood forests in several states in the eastern United States (1). Many of the early studies on the occurrence and distribution of this pathogen in soil focused on loblolly and shortleaf pine stands where littleleaf disease was or could be a problem.

The results of this study corroborate conclusions from these previous studies that $P$. cinnamomi is well-established and appears to be widely distributed in the southern Appalachian Mountain region. In 2002, P. cinnamomi was found in approximately $40 \%$ of the soil samples collected in the Jocassee Gorges Natural Area in the northwestern corner of South Carolina (64), which adds further confirmation to the establishment of this pathogen in the region. $P$. cinnamomi also is the species found most frequently attacking or associated with woody ornamental crops in South Carolina (S. N. Jeffers, unpublished), and it is common on these crops elsewhere in the United States (31).

Although reported much less frequently, $P$. heveae has been recovered from soils in the southern Appalachian Mountains in previous studies $(12,26)$. More recently, $P$. heveae also was found in forest soils in the Jocassee Gorges Natural Area of South Carolina along with $P$. cinnamomi (65), in western North Carolina in forest streams (28), and on rhododendron foliage in a forest site (28). In addition to these reports, it has been isolated from diseased rhododendron shoots in ornamental crop nurseries in western North Carolina (5) and on rhododendron and viburnum nursery crops in Oregon (45). More commonly, it has been found causing cankers on trunks of avocado trees in Central America and bud rot on coconut trees in Africa and attacking rubber trees in Malaysia

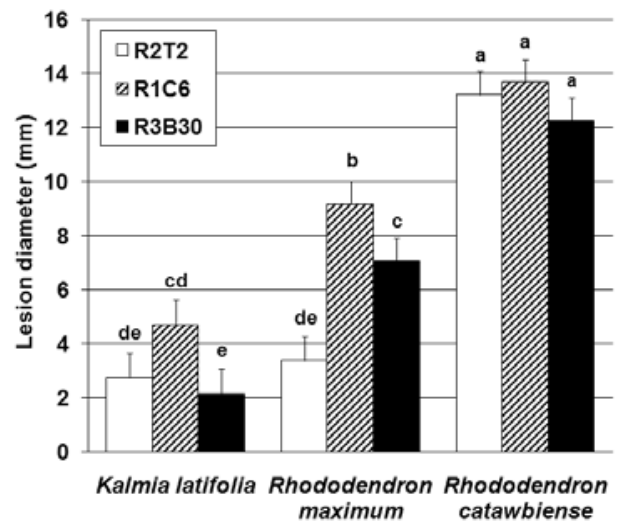

Fig. 3. Mean lesion diameters produced by three isolates of Phytophthora heveae (R2T2, R1C6, and R3B30) on wounded, detached leaves of three plant species. Data were analyzed by 2-way analysis of variance, and there was a significant isolate $\times$ plant interaction; therefore, individual means without a letter in common are significantly different (Fisher's protected least significant difference, $\alpha=0.05$ ). Error bars equal standard errors.
(17). Like P. cinnamomi, $P$. heveae appears to be well-established in the forest soils of the southern Appalachian Mountains; however, it occurs much less frequently than $P$. cinnamomi in these ecosystems.

In general, there was no effect of fuel reduction treatments on incidence of Phytophthora spp. in the hardwood forest soils of the Green River Game Land in western North Carolina during the 7year duration of this study, including the 5 years after treatments were initiated. There are several possible explanations for this. Mechanical fuel reduction killed much of the host tissue (58), but this did not impact survival of Phytophthora spp. in our studyeither because there were enough active roots remaining, as evidenced by sprouting of some cut stems (59), or the pathogens were able to survive in the absence of host material. In addition, heat produced from the low-intensity fires apparently did not elevate soil temperatures high enough to affect survival. There is a lack of information in the literature on the direct effect of prescribed fire on soil temperatures in forest ecosystems $(6,49)$.

Phytophthora spp. most commonly persist in soil as resting propagules such as chlamydospores and oospores, which can withstand extremes in environmental conditions and persist in the absence of host tissue (17), so these propagules may have been relatively unaffected by removal of shrubby understory plants and heat from the fires. Also, these propagules can occur in soils at depths where they are not likely to be directly impacted by the heat produced from a prescribed fire $(41,63)$. In fact, several studies have demonstrated that some species of Phytophthora (e.g., P. lateralis Tucker \& Milbrath, $P$. ramorum, and $P$. cinnamomi) still could be detected in forest soils after prescribed fire $(15,16,20,23,25,37$, $39,63)$, although in some cases, inoculum levels were reduced. In our study, soils were sampled to a depth of 10 to $20 \mathrm{~cm}$, but occurrence of Phytophthora spp. at specific depths was not determined. Consequently, we initiated a study to examine the direct effects of prescribed fire on survival of $P$. cinnamomi in forest soil (42).

Table 4. Percentages of mountain laurel, white pine, Sawara cypress, and Leyland cypress plants killed by 11 isolates of Phytophthora cinnamomi recovered from forest soils, by one isolate of $P$. cinnamomi isolated from each host plant, and in a noninoculated control treatment after 18 weeks in a greenhouse $^{\mathrm{w}}$

\begin{tabular}{lcccc}
\hline & \multicolumn{4}{c}{ Mortality $(\boldsymbol{\%})^{\mathbf{x}}$} \\
\cline { 2 - 5 } Isolate & $\begin{array}{c}\text { Mountain } \\
\text { laurel } \\
(\boldsymbol{n}=\mathbf{1 0})\end{array}$ & $\begin{array}{c}\text { White pine } \\
(\boldsymbol{n}=\mathbf{6})\end{array}$ & $\begin{array}{c}\text { Sawara } \\
\text { cypress } \\
(\boldsymbol{n}=\mathbf{1 0})\end{array}$ & $\begin{array}{c}\text { Leyland } \\
\text { cypress } \\
(\boldsymbol{n}=\mathbf{8})\end{array}$ \\
\hline 1 & 100 & 66 & 10 & 0 \\
2 & 90 & 100 & 20 & 0 \\
3 & 100 & 83 & 0 & 0 \\
4 & 90 & 100 & 0 & 0 \\
5 & 90 & 66 & 0 & 0 \\
6 & 90 & 83 & 0 & 0 \\
7 & 100 & 100 & 0 & 0 \\
8 & 80 & 83 & 10 & 0 \\
9 & 90 & 66 & 0 & 0 \\
10 & 80 & 100 & 20 & 0 \\
11 & 90 & 83 & 0 & 0 \\
Host & 100 & 66 & 0 & 0 \\
Control & 10 & 33 & 0 & 0 \\
$P>X^{2}, 12 \mathrm{df}^{\mathrm{y}}$ & $<0.001$ & 0.004 & 0.173 & $\ldots$ \\
$P>X^{2}, 11 \mathrm{df}^{z}$ & 0.764 & 0.567 & 0.195 & $\ldots$ \\
\hline
\end{tabular}

w Plants were not inoculated (control) or inoculated by infesting the soilless container mix in which they were growing with rice grains colonized by P. cinnamomi.

${ }^{x}$ Percentages are based on numbers of plants that died in two trials. In each trial, five mountain laurel, three white pine, five Sawara cypress, and four Leyland cypress plants were used for each treatment.

y Probability of a greater chi-square value occurring for all 13 treatments, using $0 \%$ mortality from $P$. cinnamomi for the control treatments for mountain laurel and white pine (see text). ... = Not tested.

${ }^{\mathrm{z}}$ Probability of a greater chi-square value occurring for the 12 isolates. $\ldots=$ Not tested. 
Although there was no direct effect of fuel reduction treatments on the incidence of Phytophthora spp. in soil, there was an increase in incidence over time, particularly from 2004 to 2007. The source of this difference could be due to several factors. First, the region had been experiencing drought conditions from 1998 to 2002, which may have affected persistence and recovery of Phytophthora spp. in the first two sample periods. Seasonal fluctuations in recovery of $P$. cinnamomi due to changes in precipitation have been reported (50) and may have been a factor in the differences observed in our study. Second, although the same protocol and equipment were used, the samples in 2002 and 2004 were collected and processed by a different individual than those collected and processed in 2007. Therefore, the greater incidence in 2007 may be due to a human factor. Third, because numerous individual researchers were involved with the Fire and Fire Surrogate Study, there was an unusually high amount of foot traffic at the study site; therefore, infested soil on shoes and equipment may have been transferred among sample plots within treatment areas. However, recovery of Phytophthora spp. in sample plots between sample periods was consistent. Therefore, presence or absence of Phytophthora spp. in specific sample plots remained relatively unchanged throughout the duration of this project.

As fuel reduction treatments continue to be used in forests of the southern Appalachian Mountains, there are other factors that could affect the incidences of these plant pathogens. Changes in plant species composition or in the soil microbiota caused by fuel reduction treatments might increase or decrease incidences of Phytophthora spp. Slow-moving, low-intensity fires could have relatively major impacts on the forest floor, and this, in turn, could affect inoculum levels in a positive or negative way. Removal of the litter layer and opening the plant canopy could cause soil to dry more quickly, creating a less hospitable environment for species of Phytophthora due to their dependence on soil moisture. Conversely, populations of microorganisms antagonistic to Phytophthora spp. also might be negatively affected by removal of organic matter in the top layer of soil, thus creating a less competitive environment for the pathogen. Overall, fuel reduction treatments do not appear to affect the incidence of Phytophthora spp. in soil; however, evaluation of the plots in this study site after a longer period of time or after additional treatment applications may be necessary to fully understand how these treatments will impact long-term survival of species of Phytophthora in forest soil in this southern Appalachian Mountain site.

Results on the efficiency of the soil baiting bioassay indicated that removing baits at $24 \mathrm{~h}$ was as effective at detecting $P$. cinnamomi as removing them at $72 \mathrm{~h}$, and that baiting fresh soil with camellia leaf disks was the most effective way to recover this species from forest soils. However, detection of $P$. heveae was most effective when air-dried soils were baited with camellia leaf disks for $72 \mathrm{~h}$. Wood (64) used a very similar bioassay procedure for soils from the Jocassee Gorges Natural Area in South Carolina and had similar findings for detection of $P$. cinnamomi. However, she found that detection of $P$. heveae was most effective using hemlock needles and fresh soil. In both studies, $P$. heveae was detected using camellia and hemlock baits and in fresh and air-dried soil; differences in detection levels were only a matter of degree. In fact, in 2007, we only baited fresh soil samples and removed all baits after $72 \mathrm{~h}$ based on results from 2002 and 2004, and detection of $P$. heveae was similar in all three sample periods. It is understandable that detection of $P$. cinnamomi declined in air-dried soil samples because $P$. cinnamomi persists in soil primarily as chlamydospores, and these structures apparently can be sensitive to desiccation (I. M. Meadows and S. N. Jeffers, unpublished). In contrast, detection of $P$. heveae was greater in air-dried soil, most likely because this species is homothallic and primarily survives as oospores (17). Previously, it has been demonstrated that air drying soil can improve detection of homothallic species-presumably by stimulating germination of oospores (29). Continued evaluation and refinement of the baiting bioassay will improve detection of Phytophthora spp. in future investigations.
Results from laboratory trials with forest isolates of $P$. heveae demonstrated that they had the potential to be weak, opportunistic pathogens of two native plant species-neither of which are documented hosts of this species. $R$. maximum has been reported to be susceptible to $P$. heveae by artificial inoculation $(5,17)$, but the pathogen has never been isolated from this host in nature. Lesions only were produced on areas of leaves that had been wounded prior to inoculation, and this method of inoculation probably is not an accurate representation of what occurs in nature. In contrast, Benson and Jones (5) demonstrated that isolates of $P$. heveae isolated from cultivated rhododendron shoots were able to infect and colonize nonwounded leaves of cultivated rhododendron under optimum conditions. In our study, within the genus Rhododendron, lesion size was smaller on leaves of the native $R$. maximum than on leaves of the cultivated species $R$. catawbiense 'English Roseum'; Benson and Jones (5) also found native rhododendron to be less susceptible than cultivated rhododendron. The three isolates of $P$. heveae also appeared to vary in virulence on two of the three plants tested, K. latifolia 'Peppermint' and $R$. maximum, but were equally virulent on $R$. catawbiense 'English Roseum'. P. heveae, therefore, has the potential to be pathogenic to both $K$. latifolia and $R$. maximum in the forest ecosystem.

Greenhouse trials with $P$. cinnamomi demonstrated that isolates naturally present in forest soils can be virulent on both mountain laurel and white pine, two species known to be hosts for this pathogen (67), and forest isolates were as virulent as isolates previously recovered from these two host plants. In addition, mountain laurel and white pine were more susceptible to root rot caused by $P$. cinnamomi than Leyland cypress or Sawara cypress-at least under the experimental conditions used in this study. Leyland cypress and Sawara cypress were not susceptible in our experiment and have not been demonstrated to be hosts previously; however, $P$. cinnamomi has been recovered from diseased plants of both cypress species on multiple occasions in South Carolina (S. N. Jeffers, unpublished). Modifications to this experiment might have produced different results for Leyland cypress and Sawara cypressincluding increased inoculum load (i.e., more rice grains per pot), a longer flooding duration, and more flooding episodes.

Despite the potential for these two species to cause disease, there was no evidence that either $P$. cinnamomi or $P$. heveae was causing disease on native plant species in the study site, even though numerous susceptible plant species were present. $P$. cinnamomi has been established for many years in the southern Appalachian Mountain region $(13,67)$; therefore, it is possible that species or individuals within a species that are most susceptible to this pathogen already have been attacked and killed (e.g., American chestnut [14]), and only more resistant plant species or family lines remain. Occurrence of both $P$. cinnamomi and $P$. heveae in areas where disease symptoms were absent has been noted in the past $(13,21,26,32,64)$. Consequently, the roles of $P$. cinnamomi and $P$. heveae in the forest ecosystem of the southern Appalachian Mountains are unclear and warrant further study.

\section{Acknowledgments}

We thank all of those who helped with the various aspects of this project, including laboratory, greenhouse, and field work: L. A. Luszcz, R. B. Baker, M. Smith, E. Robayo-Camacho, F. McLaughlin, E. Sachs, and A. K. Wood. We also thank the USDA Forest Service personnel who established and maintained the study site. This study was supported financially by the Joint Fire Science Program, the U.S. Forest Service National Fire Plan, and the U.S. Forest Service, Southern Research Station, Center for Forest Disturbance Research (SRS-4156). This is Contribution Number 188 of the National Fire and Fire Surrogate Project. This material also is based on work supported by the CSREES/USDA under project number SC-1700177; Technical Contribution No. 5823 of the Clemson University Experiment Station.

\section{Literature Cited}

1. Balci, Y., Balci, S., Eggers, J., MacDonald, W. L., Juzwik, J., Long, R. P., and Gottschalk, K. W. 2007. Phytophthora spp. associated with forest soils in eastern and north-central U.S. oak ecosystems. Plant Dis. 91:705-710.

2. Balci, Y., and Halmschlager, E. 2003. Incidence of Phytophthora species in oak forests in Austria and their possible involvement in oak decline. For. Pathol. 33:157-174 
3. Balci, Y., and Halmschlager, E. 2003. Phytophthora species in oak ecosystems in Turkey and their association with declining oak trees. Plant Pathol. 52:694-702.

4. Barrett, S. W. 1988. Fire suppression's effects on forest succession within a central Idaho wilderness. West. J. Appl. For. 3:76-80.

5. Benson, D. M., and Jones, R. K. 1980. Etiology of Rhododendron dieback caused by four species of Phytophthora. Plant Dis. 64:687-691.

6. Boerner, R. E. J. 2006. Soil, fire, water, and wind: How the elements conspire in the forest context. Pages 104-122 in: Fire in Eastern Oak Forests: Delivering Science to Land Managers, Proceedings of a Conference. Gen. Tech. Rep. NRS-P-1. U.S. Dep. Agric. For. Serv., Newton Square, PA.

7. Brasier, C. M., Beales, P. A., Kirk, S. A., Denman, S., and Rose, J. 2004. Phytophthora kernoviae sp. nov., an invasive pathogen causing bleeding stem lesions on forest trees and foliar necrosis of ornamentals in the UK. Mycol. Res. 109:853-859.

8. Brasier, C., Denman, S., Brown, A., and Webber, J. 2004. Sudden oak death (Phytophthora ramorum) discovered on trees in Europe. Mycol. Res. 108:1108-1110

9. Brasier, C. M., Kirk, S. A., Delcan, J., Cooke, D. E. L., Jung, T., and Man in't Veld, W. A. 2005. Phytophthora alni sp. nov. and its variants: Designation of emerging heteroploid hybrid pathogens spreading on Alnus trees. Mycol. Res. 108:1172-1184.

10. Burgess, T. I., Webster, J. L., Ciampini, J. A., White, D., Hardy, G. E. St. J., and Stukely, M. J. C. 2009. Re-evaluation of Phytophthora species isolated during 30 years of vegetation health surveys in Western Australia using molecular techniques. Plant Dis. 93:215-223.

11. Campbell, W. A. 1951. The occurrence of Phytophthora cinnamomi in the soil under pine stands in the southeast. Phytopathology 41:742-746.

12. Campbell, W. A., and Gallegly, M. E. 1965. Phytophthora heveae from eastern Tennessee and western North Carolina. Plant Dis. Rep. 49:233-234.

13. Campbell, W. A., Gooding, G. V., Jr., and Haasis, F. A. 1963. The occurrence of Phytophthora cinnamomi in Kentucky, North Carolina, Tennessee, and Virginia. Plant Dis. Rep. 47:924-926.

14. Crandall, B. S., Gravatt, G. F., and Ryan, M. M. 1945. Root disease of Castanea species and some coniferous and broadleaf nursery stocks, caused by Phytophthora cinnamomi. Phytopathology 35:162-180.

15. Dawson, P., Weste, G., and Ashton, D. 1985. Regeneration of vegetation in the Brisbane Ranges after fire and infestation by Phytophthora cinnamomi. Aust. J. Bot. 33:15-26.

16. DeNitto, G. 1993. Biological evaluation of the use of fire to eradicate Phytophthora lateralis from a site near Camp Six Lookout, Gasquet RD. FPM Report No. N93-3. U.S. Dep. Agric. For. Serv., Portland, OR.

17. Erwin, D. C., and Ribeiro, O. K. 1996. Phytophthora Diseases Worldwide. American Phytopathological Society, St. Paul, MN.

18. Ferguson, A. J., and Jeffers, S. N. 1999. Detecting multiple species of Phytophthora in container mixes from ornamental crop nurseries. Plant Dis. 83:1129-1136.

19. Goheen, E. M., Hansen, E. M., Kanaskie, A., McWilliams, M. G., Osterbauer, N., and Sutton, W. 2002. Sudden oak death caused by Phytophthora ramorum in Oregon. Plant Dis. 86:441.

20. Goheen, E., Hansen, E., Kanaskie, A., McWilliams, M., Osterbauer, N., Sutton, W., and Rehms, L. 2004. An eradication strategy for Phytophthora ramorum in Oregon coastal forests. (Abstr.) Phytopathology 94:S35.

21. Hansen, E. M. 2001. Phytophthora in the Americas-2001. Pages 19-24 in: Phytophthora in Forests and Natural Ecosystems. 2nd IUFRO Working Party 7.02.09 Meeting, Albany, W. Australia. J. A. McComb, G. E. St. J. Hardy, and I. C. Tommerup, eds. Murdoch University Print, Western Australia.

22. Hansen, E. M., and Delatour, C. 1999. Phytophthora species in oak forests of north-east France. Ann. For. Sci. 56:539-547.

23. Hansen, E. M., Kanaskie, A., Prospero, S., McWilliams, M., Goheen, E. M., Osterbauer, N., Reeser, P., and Sutton, W. 2008. Epidemiology of Phytophthora ramorum in Oregon tanoak forests. Can. J. For. Res. 38:11331143.

24. Hansen, E. M., Reeser, P. W., Davidson, J. M., Garbelotto, M., Ivors, K., Douhan, L., and Rizzo, D. M. 2003. Phytophthora nemorosa, a new species causing cankers and leaf blight of forest trees in California and Oregon, USA. Mycotaxon 88:129-138.

25. Hansen, E. M., and Sutton, W. 2005. Persistence of Phytophthora ramorum after eradication efforts in Oregon tanoak forests. Page 516 in: Proc. 2nd Sudden Oak Death Sci. Sympos.: The State of Our Knowledge. S. J. Frankel, P. J. Shea, and M. I. Haverty, tech. coords. Gen. Tech. Rep. PSWGTR-196. U.S. Dep. Agric. For. Serv., Albany, CA.

26. Hendrix, F. F., Jr., Campbell, W. A., and Chien, C. Y. 1971. Some Phycomycetes indigenous to soils of old growth forests. Mycologia 63:283-289.

27. Holmes, K. A., and Benson, D. M. 1994. Evaluation of Phytophthora parasitica var. nicotianae as a biocontrol for Phytophthora parasitica on Catharanthus roseus. Plant Dis. 78:193-199.

28. Hwang, J., Oak, S. W., and Jeffers, S. N. 2009. Monitoring the occurrence of Phytophthora species in forest streams in North Carolina using baiting and filtration methods. Pages 91-95 in: Phytophthora in Forests and Natural Ecosystems. Proc. 4th Meeting IUFRO Working Party S07.02.09. E. M. Goheen and S. J. Frankel, tech. coords. Gen. Tech. Rep. PSW-GTR-22. U.S. Dep. Agric. For. Serv., Albany, CA.
29. Jeffers, S. N., and Aldwinckle, H. S. 1987. Enhancing detection of Phy tophthora cactorum in naturally infested soil. Phytopathology 77:14751482.

30. Jeffers, S. N., and Martin, S. B. 1986. Comparison of two media selective for Phytophthora and Pythium species. Plant Dis. 70:1038-1043.

31. Jones, R. K., and Benson, D. M., eds. 2001. Diseases of Woody Ornamentals and Trees in Nurseries. American Phytopathological Society, St. Paul, $\mathrm{MN}$

32. Jordan, A. P., and Tainter, F. H. 1996. The susceptibility of southern Appalachian oaks to Phytophthora cinnamomi. Castanea 61:348-355.

33. Jung, T., Blaschke, H., and Oßwald, W. 2000. Involvement of soilborne Phytophthora species in central European oak decline and the effect of site factors on the disease. Plant Pathol. 49:706-718.

34. Jung, T., Cooke, D. E. L., Blaschke, H., Duncan, J. M., and Oßwald, W. 1999. Phytophthora quercina sp. nov., causing root rot of European oaks. Mycol. Res. 103:785-798.

35. Jung, T., Hansen, E. M., Winton, L., Oßwald, W., and Delatour, C. 2002. Three new species of Phytophthora from European oak forests. Mycol. Res. 106:397-411.

36. Jung, T., Nechwatal, J., Cooke, D. E. L., Hartmann, G., Blaschke, M. Oßwald, W., Duncan, J., and Delatour, C. 2003. Phytophthora pseudosyringae sp. nov., a new species causing root and collar rot of deciduous trees in Europe. Mycol. Res. 107:772-789.

37. Kanaskie, A., Osterbauer, N., McWilliams, M., Goheen, E., Hansen, E., and Sutton, W. 2005. Eradication of Phytophthora ramorum in Oregon forestsstatus after 3 years. Pages 489-490 in: Proc. 2nd Sudden Oak Death Sci. Sympos.: The State of Our Knowledge. S. J. Frankel, P. J. Shea, and M. I. Haverty, tech. coords. Gen. Tech. Rep. PSW-GTR-196. U.S. Dep. Agric. For. Serv., Albany, CA.

38. Kilgore, E. V., and Taylor, D. 1979. Fire history of a sequoia-mixed conifer forest. Ecology 60:129-142.

39. Marks, G. C., Kassaby, F. Y., and Fagg, P. C. 1975. Variation in population levels of Phytophthora cinnamomi in Eucalyptus forest soils of eastern Victoria. Aust. J. Bot. 23:435-449.

40. Martin, F. M., and Tooley, P. W. 2003. Phylogenetic relationships of Phytophthora ramorum, $P$. nemorosa, and $P$. pseudosyringae, three species recovered from areas in California with sudden oak death. Mycol. Res. 107:1379-1391.

41. McLaughlin, I. M., and Jeffers, S. N. 2009. Spatial distribution of Phytophthora cinnamomi in forest soils of the Carolinas. (Abstr.) Phytopathology 99:S82.

42. McLaughlin, I. M., Jeffers, S. N., and Waldrop, T. A. 2007. Effects of prescribed burning on survival of Phytophthora cinnamomi in forest soil. (Abstr.) Phytopathology 97:S74.

43. McLaughlin, I. M., Jeffers, S. N., and Waldrop, T. A. 2008. Long-term effects of fuel reduction treatments on the incidence of Phytophthora spp. in soil of a hardwood forest in the southern Appalachian Mountains. (Abstr.) Phytopathology 98:S102.

44. Mircetich, S. M., Campbell, R. N., and Matheron, M. E. 1977. Phytophthora trunk canker of coast live oak and cork oak trees in California. Plant Dis. Rep. 61:66-70.

45. Osterbauer, N. K., Griesbach, J. A., and Hedburg, J. 2004. Surveying for and eradicating Phytophthora ramorum in agricultural communities. Plant Health Progress Online, doi:10.1094/PHP-2004-02-RS

46. Pyne, S. J. 2004. Tending Fire: Coping With America's Wildland Fires Island Press, Washington, DC.

47. Reeser, P. W., Hansen, E. M., and Sutton, W. 2007. Phytophthora siskiyouensis, a new species from soil, water, myrtlewood (Umbellularia califor nica) and tanoak (Lithocarpus densiflorus) in southwestern Oregon. Mycologia 99:639-643

48. Rizzo, D. M., Garbelotto, M., Davidson, J. M., Slaughter, G. W., and Koike, S. T. 2002. Phytophthora ramorum as the cause of extensive mortality of Quercus spp. and Lithocarpus densiflorus in California. Plant Dis. 86:205214.

49. Robichaud, P. R., and Waldrop, T. A. 1994. A comparison of surface runoff and sediment yields from low- and high-severity site preparation burns. Water Res. Bull. 30:27-34

50. Shearer, B. L., and Shea, S. R. 1987. Variation in seasonal population fluctuations of Phytophthora cinnamomi within and between infected Eucalyptus marginata sites of southwestern Australia. For. Ecol. Manag. 21:209230.

51. Sinclair, W. A., and Lyon, H. 2005. Diseases of Trees and Shrubs, 2nd ed. Cornell University Press, Ithaca, NY

52. Stamps, D. J., Waterhouse, G. M., Newhook, F. J., and Hall, G. S. 1990 Revised Tabular Key to the Species of Phytophthora. Mycol. Pap., No. 162 C.A.B. International, Oxon, UK

53. Tainter, F. H., O’Brien, J. G., Hernandez, A., Orozco, F., and Rebolledo, O 2000. Phytophthora cinnamomi as a cause of oak mortality in the state of Colima, Mexico. Plant Dis. 84:394-398.

54. Tippett, J. T., McGrath, J. F., and Hill, T. C. 1989. Site and seasonal effects on susceptibility of Eucalyptus marginata to Phytophthora cinnamomi. Aust. J. Bot. 37:481-490.

55. Vankat, J. L. 1977. Fire and man in Sequoia National Park. Ann. Assoc. Am. Geogr. 67:17-27. 
56. Vettraino, A. M., Barzanti, G. P., Bianco, M. C., Ragazzi, A., Capretti, P., Paoletti, E., Luisi, N., Anselmi, N., and Vannini, A. 2002. Occurrence of Phytophthora species in oak stands in Italy and their association with declining oak trees. For. Pathol. 32:19-28.

57. Waldrop, T. A., and McIver, J. 2006. The National Fire and Fire Surrogate Study: Early results and future challenges. Pages 526-530 in: Proc. 13th Bienn. Southern Silvicultural Res. Conf. K. F. Conner, ed. Gen. Tech. Rep. SRS-92. U.S. Dep. Agric. For. Ser., Asheville, NC.

58. Waldrop, T. A., Phillips, R. J., and Simon, D. A. 2010. Fuels and predicted fire behavior in eastern hardwood and pine-hardwood stands following fire and fire surrogate treatments. For. Sci. 56:32-45.

59. Waldrop, T. A., Yaussy, D. A., Phillips, R. J., Hutchinson, T. A., Brudnak, L., and Boerner, R. E. J. 2008. Fuel reduction treatments affect stand structure of hardwood forests in Western North Carolina and Southern Ohio, USA. For. Ecol. Manag. 255:3117-3129.

60. Waterhouse, G. M. 1963. Key to the Species of Phytophthora de Bary. Mycol. Pap., No. 92. Commonwealth Mycological Institute, Surrey, UK.

61. Waterhouse, G. M. 1970. The Genus Phytophthora de Bary. Mycol. Pap., No. 122. Commonwealth Mycological Institute, Surrey, UK.

62. Weatherspoon, C. P., and McIver, J. D. 2000. A national study of the consequences of fire and fire surrogate treatments. Executive Summary for the Fire and Fire Surrogate Study, proposal submitted to the Joint Fire Science
Program. Available online at the Fire Research and Management Exchange System. Retrieved 21 February 2011 from http://frames.nbii.gov/portal/ server.pt?open $=512 \&$ objID $=367 \&$ PageID $=1570 \&$ mode $=2 \&$ in_hi_userid=3 $82 \&$ cached $=$ true.

63. Weste, G. 1974. Phytophthora cinnamomi-the cause of severe disease in certain native communities in Victoria. Aust. J. Bot. 22:1-8

64. Wood, A. K. 2002. The Role of Phytophthora Species in Forest Ecosystems in the Southeastern United States and Mexico. M.S. thesis. Clemson University, Clemson, SC.

65. Wood, A. K., and Tainter, F. H. 2002. First report of Phytophthora cinnamomi on Quercus laurifolia. Plant Dis. 86:441.

66. Woods, F. W. 1953. Disease as a factor in the evolution of forest composition. J. For. 51:871-873.

67. Zentmyer, G. A. 1980. Phytophthora cinnamomi and the Diseases it Causes. Monogr. No. 10. American Phytopathological Society, St. Paul, MN.

68. Zwart, D. C., Jeffers, S. N., and Waldrop, T. A. 2004. Incidences of Phytophthora spp. in a hardwood forest site in the southern Appalachian Mountains. (Abstr.) Phytopathology 94:S118.

69. Zwart, D. C., Jeffers, S. N., Waldrop, T. A., and Bridges, W. C., Jr. 2005 Effects of fuel reduction treatments on detection of Phytophthora spp. in soil in an Appalachian Mountain forest. (Abstr.) Phytopathology 95:S119. 